\title{
Electron Capture Dissociation Mass Spectrometry of Metallo-Supramolecular Complexes
}

\author{
Malgorzata A. Kaczorowska, a Anna C. G. Hotze, ${ }^{b}$ Michael J. Hannon, \\ and Helen J. Cooper ${ }^{a}$ \\ a School of Biosciences, College of Life and Environmental Sciences, University of Birmingham, Edgbaston, \\ Birmingham, United Kingdom \\ ${ }^{b}$ School of Chemistry, College of Engineering and Physical Sciences, University of Birmingham, Edgbaston, \\ Birmingham, United Kingdom
}

The electron capture dissociation (ECD) of metallo-supramolecular dinuclear triple-stranded helicate $\mathrm{Fe}_{2} \mathrm{~L}_{3}{ }^{4+}$ ions was determined by Fourier transform ion cyclotron resonance mass spectrometry. Initial electron capture by the di-iron(II) triple helicate ions produces dinuclear double-stranded complexes analogous to those seen in solution with the monocationic metal centers $\mathrm{Cu}^{\mathrm{I}}$ or $\mathrm{Ag}^{\mathrm{I}}$. The gas-phase fragmentation behavior [ECD, collision-induced dissociation (CID), and infrared multiphoton dissociation (IRMPD)] of the di-iron double-stranded complexes, (i.e., $\mathrm{MS}^{3}$ of the ECD product) was compared with the ECD, CID, and IRMPD of the $\mathrm{Cu}^{\mathrm{I}}$ and $\mathrm{Ag}^{\mathrm{I}}$ complexes generated from solution. The results suggest that iron-bound dimers may be of the form $\mathrm{Fe}_{2}{ }_{2} \mathrm{~L}_{2}{ }^{2+}$ and that ECD by metallo-complexes allows access, in the gas phase, to oxidation states and coordination chemistry that cannot be accessed in solution. (J Am Soc Mass Spectrom 2010, 21, 300-309) (C) 2010 American Society for Mass Spectrometry

$\mathrm{T}$ The benefits of mass spectrometry in the study of supramolecular chemistry are several: investigation of molecules and complexes in the gas phase allows determination of the intrinsic properties without interference from solvent or counter ion [1]. Comparison of gas- and condensed-phase behavior provides information on solvation effects. While most applications of MS to supramolecular assemblies focus on soft ionization techniques, e.g., coldspray [2] and desorption electrospray ionization (DESI) [3], to retain the assembly intact, structural information can be gained by tandem mass spectrometry (MS/MS) in which precursor ions are characterized according to their fragment ions. It is also possible to obtain information regarding fundamental reactivity by MS/MS. To date, MS/MS techniques applied to supramolecular chemistry include collision-induced dissociation (CID) to obtain structural information [4], infrared multiphoton dissociation (IRMPD) for the study of reactivity and mechanisms of fragmentation in the gas phase [5-7], and blackbody infrared radiation dissociation (BIRD) for the study of gas-phase kinetics [8].

Here, we have applied electron capture dissociation (ECD) to the study of metallo-supramolecular doubleand triple-stranded helicates. Electron capture dissociation (ECD) $[9,10]$ is a relatively recent tandem mass

Address reprint requests to Dr. H. J. Cooper, School of Biosciences, College of Life and Environmental Sciences, University of Birmingham, Edgbaston, Birmingham B15 2TT, UK. E-mail: H.J.Cooper@bham.ac.uk spectrometry technique in which trapped ions are irradiated with low-energy electrons provided by a heated dispenser cathode [11]. (The requirement for trapped ions and electrons means that ECD is generally only performed in a Fourier transform ion cyclotron resonance (FT-ICR) [12] mass spectrometer). As with other recent technological advances in mass spectrometry, the development of ECD has been driven by its application to biosciences, particularly in the analysis of peptides and proteins, although the technique has recently been applied to some synthetic macromolecules, such as polymers and dendrimers [13-19]. The ECD of metalbound peptide [20-23] and lipid complexes [24], magnesium ammonia complexes [25], and lanthanide complexes [26] have also been studied.

The metallo-supramolecular triple helicates studied herein self-assemble in solution via coordination of the ligands shown in Figure 1 to octahedral metal ions [27], in this case $\mathrm{Fe}^{\mathrm{II}}$. Coordination to the metal center causes twisting along the ligand strand (e.g., between the phenylene rings and the adjacent pyridylimine units) and three ligand strands wrap about two metal ions giving rise to a triple helical structure. In addition to the metal-ligand interactions, which drive the formation, the structure is stabilized via interstrand face-edge $\pi$-stacking interactions between the phenylene rings of the spacer groups. If the ligands are reacted with tetrahedral metal ions, such as $\mathrm{Cu}^{\mathrm{I}}$ and $\mathrm{Ag}^{\mathrm{I}}$, dinuclear double-stranded cations $\left[\mathrm{M}_{2} \mathrm{~L}_{2}\right]^{2+}$ are produced $[28,29]$. These dinuclear double-stranded species exists in two 

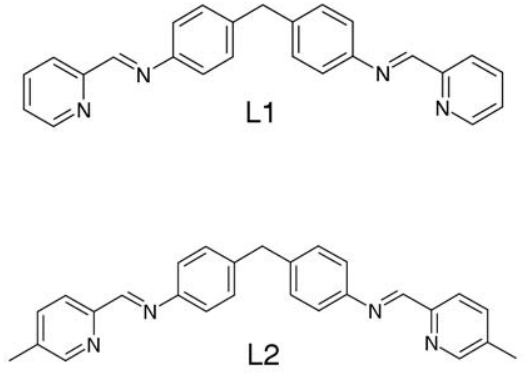

(a)
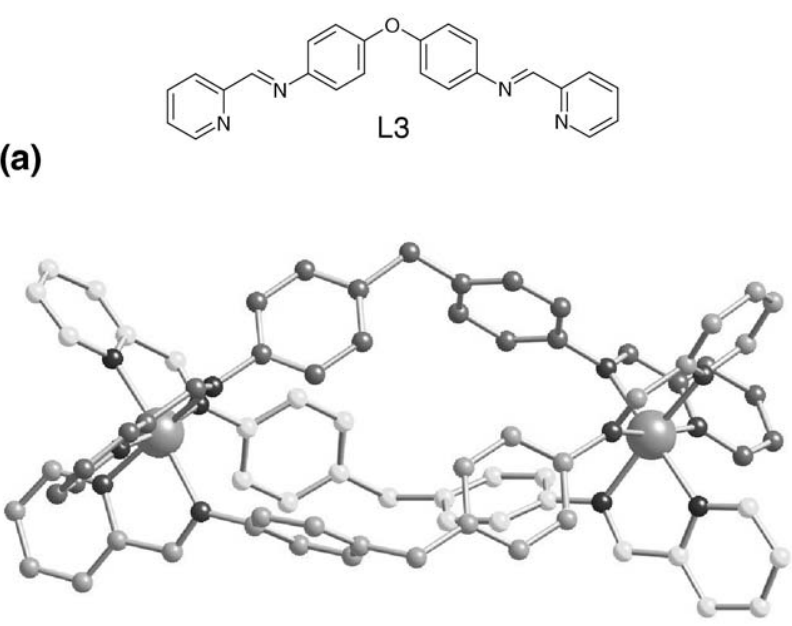

(b)

Figure 1. (a) Structures of ligands L1, L2, and L3; (b) Structure of the iron triple-helicates derived from ligand L1 (hydrogens are omitted for clarity).

conformations: a double helix (rac-isomer) and a box structure (meso-isomer), with the latter favored at low temperatures. These double- and triple-stranded arrays are not only representative of a wide class of metallosupramolecular species but also provide rare examples of functional supramolecular species, showing unique and unprecedented DNA recognition properties [30-32].

We demonstrate that ECD by metallo-complexes may allow access in the gas phase to oxidation states and coordination chemistry that cannot be accessed in solution. Electron capture by the di-iron(II) triple helicate ions produces dinuclear double-stranded complexes analogous to those seen in solution with the monocationic metal centers $\mathrm{Cu}^{\mathrm{I}}$ or $\mathrm{Ag}^{\mathrm{I}}$. We compare the ECD, CID, and IRMPD fragmentation behavior of the di-iron doublestranded complexes, (i.e., $\mathrm{MS}^{3}$ of the product of ECD) with that observed for the $\mathrm{Cu}^{\mathrm{I}}$ and $\mathrm{Ag}^{\mathrm{I}}$ complexes generated from solution. The fragmentation behavior observed tracks with the first ionization energies of the metal ions. The results also demonstrate that ECD has an important role to play in chemical structure determination, i.e., the technique has far wider applicability than its current usage (primarily biomolecular analysis) would imply.

\section{Experimental}

The $\mathrm{Fe}^{\mathrm{II}}$ metallo-supramolecular triple-stranded helicates (as chloride salts) and $\mathrm{Cu}^{\mathrm{I}}$ and $\mathrm{Ag}^{\mathrm{I}}$ metallosupramolecular double-stranded complexes (as chloride salts) were prepared as previously described [27].

FT-ICR Mass Spectrometry of $\mathrm{Fe}_{2} \mathrm{~L}_{3}{ }^{4+}, \mathrm{Cu}_{2} \mathrm{~L}_{2}{ }^{2+}$, and $\mathrm{Ag}_{2} \mathrm{~L}_{2}{ }^{2+}$

Solutions of the $\mathrm{Fe}^{\mathrm{II}}, \mathrm{Cu}^{\mathrm{I}}$ and $\mathrm{Ag}^{\mathrm{I}}$ complexes were prepared by addition of water:methanol (1:1) (Fisher Scientific, Loughborough, UK), 2\% formic acid (Fisher Scientific) for a final concentration of $10 \mu \mathrm{M}$. The samples were analyzed with a Thermo Finnigan LTQ FT (Thermo Fisher Scientific, Bremen, Germany) mass spectrometer. Data acquisition was controlled by Xcalibur 2.0 software. Samples were introduced by use of a chip-based electrospray system (Nanomate, Advion Biosciences, Ithaca, NY, USA).

Electron Capture Dissociation. Precursor ions were isolated in the front-end linear ion trap. Isolation width was $10 \mathrm{Th}$. Automatic gain control (AGC) was used to accumulate sufficient precursor ions [target value $1 \times 10^{6}$ (corresponding to the number of charges)]. The electrons for ECD were provided by an indirectly heated barium tungsten cylindrical dispenser cathode $(5.1 \mathrm{~mm}$ diameter, $154 \mathrm{~mm}$ from the ICR cell, $1 \mathrm{~mm}$ off-axis). The current across the electrode was $\sim 1.1 \mathrm{~A}$. Precursor ions were irradiated for between 10 and $100 \mathrm{~ms}$ at $5 \%$ energy (corresponding to a cathode potential of $-2.55 \mathrm{~V}$ ). Each ECD scan comprised five co-added microscans, acquired with a resolution of 100,000 at $\mathrm{m} / \mathrm{z} 400$.

Collision Induced Dissociation. All CID experiments were performed in the front-end linear ion trap and the fragments transferred to the ICR cell for detection. Isolation width was $10 \mathrm{Th}$. AGC target value was $1 \times 10^{6}$. Helium gas at a normalized collision energy of $35 \%$ was used for all CID experiments.

Infrared Multiphoton Dissociation. Precursor ions were isolated in the linear ion trap. Isolation width was 10 Th. AGC target was $5 \times 10^{5}$. Photons for IRMPD were provided by an off-axis continuous wave $40 \mathrm{~W}, 10.6 \mu \mathrm{m}$ wavelength $\mathrm{CO}_{2}$ laser. Isolated precursor ions were irradiated with photons at $80 \%$ full power for $500 \mathrm{~ms}$. Each IRMPD scan comprised five co-added microscans, acquired with a resolution of 100,000 at $\mathrm{m} / \mathrm{z} 400$. All the MS and MS/MS spectra were averaged over 30 scans and analyzed manually.

FT-ICR $\mathrm{MS}^{3}$ of $\left[\mathrm{Fe}_{2} \mathrm{L1}_{2}\right]^{2+}$

FT-ICR MS ${ }^{3}$ experiments were performed on a homebuilt 9.4 T ESI-Q-FTICR mass spectrometer [33] at the National High Magnetic Field Laboratory in Tallahassee, FL. The instrument is equipped with an on-axis 
dispenser cathode-based electron gun for ECD experiments and an off-axis $\mathrm{CO}_{2}$ laser for IRMPD experiments [34]. Precursor ions of the $\left[\mathrm{Fe}_{2} \mathrm{~L}_{3}\right]^{4+}$ complex were quadrupole-isolated and accumulated for $4 \mathrm{~s}$ before transfer to the ICR cell. The ions were irradiated for 150-300 ms with electrons for ECD (cathode potential $-2.8 \mathrm{~V}$ ) followed by an electron clean-up event (in which the ECD cathode was switched to $+10 \mathrm{~V}$ for $110 \mathrm{~ms}$ ). The resultant ECD product ions $\left[\mathrm{Fe}_{2} \mathrm{L1}_{2}\right]^{2+}$ were isolated in the ICR cell by stored waveform inverse Fourier transform (SWIFT) excitation. The isolated species were then subjected to three different types of fragmentation techniques.

ECD. After SWIFT isolation of the $\left[\mathrm{Fe}_{2} \mathrm{~L} 1_{2}\right]^{2+} \mathrm{ECD}$ product ions, an addition delay of $32 \mathrm{~ms}$ was added to allow for sufficient overlap between the ion cloud and electron beam [35]. This delay was followed by a second electron irradiation event of $250 \mathrm{~ms}$ and an electron clean-up event before excitation and detection. A total of 125 scans were averaged to obtain the mass spectrum.

IRMPD. The SWIFT isolated ECD product ion was irradiated with photons at $95 \%$ laser power for $1.5 \mathrm{~s}$. A total of 85 scans were averaged to obtain the mass spectrum.

SORI-CID. For sustained off-resonance irradiation collision-induced dissociation (SORI-CID), a $3.6 \mathrm{~ms}$ pulse of He gas was injected directly into the ICR cell followed by a $500 \mu$ s single frequency excitation event 2.5 $\mathrm{KHz}$ off resonance. Ions were excited after a $20 \mathrm{~s}$ delay to allow the system to reestablish base pressure. A total of 65 scans were averaged to obtain the mass spectrum. For all $\mathrm{MS}^{3}$ experiments, before broadband detection (512 K word data points), ions were frequency-sweep excited $(72-650 \mathrm{kHz}$ at $150 \mathrm{~Hz} / \mu \mathrm{s})$.

\section{Results and Discussion}

\section{Electron Capture Dissociation of $\mathrm{Fe}_{2} \mathrm{~L}_{3}{ }^{4+}$ Ions}

The dinuclear triple-helical compounds studied are shown in Figure 1. The most abundant fragment ions observed following ECD of $\left[\mathrm{Fe}_{2} \mathrm{~L}_{3}\right]^{4+},\left[\mathrm{Fe}_{2} \mathrm{~L}_{3}\right]^{4+}$, and $\left[\mathrm{Fe}_{2} \mathrm{~L}_{3}\right]^{4+}$ are detailed in Table 1. Figure 2a shows the ECD mass spectrum obtained following irradiation of $\left[\mathrm{Fe}_{2} \mathrm{L1}_{3}\right]^{4+}$ ions with electrons for $30 \mathrm{~ms}$. The dominant product is $\left[\mathrm{Fe}_{2} \mathrm{L1}_{2}\right]^{2+}$. The charge-reduced species, i.e., $\left[\mathrm{Fe}_{2} \mathrm{L1}_{3}\right]^{3+\bullet}$, is also observed. Further increase in irradiation time to $70 \mathrm{~ms}$ results in the mass spectrum shown in Figure $2 \mathrm{~b}$. The dominant product ion is again $\left[\mathrm{Fe}_{2} \mathrm{L1}_{2}\right]^{2+}$ with additional peaks corresponding to $\left[\mathrm{Fe}_{2} \mathrm{~L} 1\right]^{+} \cdot$ and $\left[\mathrm{FeL} 1\left(\mathrm{~L} 1-\mathrm{C}_{6} \mathrm{H}_{6} \mathrm{~N}_{2}\right)\right]^{+\bullet}$ being observed. Similar results are observed for the Fe complex of ligand L2, see Figure 2c, d, and Table 1. Peaks corresponding to $\left[\mathrm{Fe}_{2} \mathrm{~L}_{3}\right]^{3+}$ and $\left[\mathrm{Fe}_{2} \mathrm{~L}_{2}\right]^{2+}$ are observed. Figure $2 \mathrm{~d}$ (electron irradiation for $100 \mathrm{~ms}$ ) shows an
Table 1. Most abundant fragment ions observed following ECD of $\left[\mathrm{Fe}_{2} \mathrm{~L}_{3}\right]^{4+},\left[\mathrm{Fe}_{2} \mathrm{~L} 2_{3}\right]^{4+}$, and $\left[\mathrm{Fe}_{2} \mathrm{~L}_{3}\right]^{4+}$. Irradiation time was $70 \mathrm{~ms}$ for $\left[\mathrm{Fe}_{2} \mathrm{~L}_{3}\right]^{4+}$, and $100 \mathrm{~ms}$ for $\left[\mathrm{Fe}_{2} \mathrm{~L}_{3}\right]^{4+}$ and $\left[\mathrm{Fe}_{2} \mathrm{~L}_{3}\right]^{4+}$

\begin{tabular}{|c|c|c|}
\hline $\mathrm{m} / \mathrm{z}_{\text {measured }}$ & $\mathrm{m} / \mathrm{z}_{\text {calculated }}$ & Assignment \\
\hline \multicolumn{3}{|l|}{$\left[\mathrm{Fe}_{2} \mathrm{~L}_{3}\right]^{4+}$} \\
\hline 310.0933 & 310.0936 & {$\left[\mathrm{Fe}_{2} \mathrm{~L} 1_{3}\right]^{4+}$} \\
\hline 413.4576 & 413.4583 & {$\left[\mathrm{Fe}_{2} \mathrm{~L} 1_{3}\right]^{3+\bullet}$} \\
\hline 432.1037 & 432.1033 & {$\left[\mathrm{Fe}_{2} \mathrm{~L} 1_{2}\right]^{2+}$} \\
\hline 487.0296 & 487.0303 & {$\left[\mathrm{Fe}_{2} \mathrm{~L} 1-\mathrm{H}\right]^{+}$} \\
\hline 488.0387 & 488.0381 & {$\left[\mathrm{Fe}_{2} \mathrm{~L} 1\right]^{+\bullet}$} \\
\hline 702.2205 & 702.2189 & {$\left[\mathrm{FeL} 1\left(\mathrm{~L} 1-\mathrm{C}_{6} \mathrm{H}_{6} \mathrm{~N}_{2}\right)\right]^{+\bullet}$} \\
\hline \multicolumn{3}{|l|}{$\left[\mathrm{Fe}_{2} \mathrm{~L}_{3}\right]^{4+}$} \\
\hline 331.1169 & 331.1171 & {$\left[\mathrm{Fe}_{2} \mathrm{~L}_{3}\right]^{4+}$} \\
\hline 441.4891 & 441.4896 & {$\left[\mathrm{Fe}_{2} \mathrm{~L} 2_{3}\right]^{3+\bullet}$} \\
\hline 460.1342 & 460.1346 & {$\left[\mathrm{Fe}_{2} \mathrm{~L}_{2}\right]^{2+}$} \\
\hline 516.0688 & 516.0694 & {$\left[\mathrm{Fe}_{2} \mathrm{~L} 2\right]^{+\bullet}$} \\
\hline 744.2639 & 744.2659 & {$\left[\mathrm{FeL} 2\left(\mathrm{~L} 2-\mathrm{C}_{7} \mathrm{H}_{8} \mathrm{~N}_{2}\right)\right]^{+}$} \\
\hline 746.2800 & 746.2815 & {$\left[\mathrm{FeL} 2\left(\mathrm{~L} 2-\mathrm{C}_{7} \mathrm{H}_{6} \mathrm{~N}_{2}\right)\right]^{+}$} \\
\hline 802.2142 & 802.2166 & {$\left[\mathrm{Fe}_{2} \mathrm{~L} 2\left(\mathrm{~L} 2-\mathrm{C}_{7} \mathrm{H}_{6} \mathrm{~N}_{2}\right)\right]^{+}$} \\
\hline 920.2668 & 920.2697 & {$\left[\mathrm{Fe}_{2} \mathrm{~L} 2_{2}\right]^{+\bullet}$} \\
\hline \multicolumn{3}{|l|}{$\left[\mathrm{Fe}_{2} \mathrm{~L}_{3}\right]^{4+}$} \\
\hline 311.5778 & 311.5780 & {$\left[\mathrm{Fe}_{2} \mathrm{~L}_{3}\right]^{4+}$} \\
\hline 415.4370 & 415.4376 & {$\left[\mathrm{Fe}_{2} \mathrm{~L}_{3}\right]^{3+\bullet}$} \\
\hline 434.0821 & 434.0825 & {$\left[\mathrm{Fe}_{2} \mathrm{L3}_{2}\right]^{2+}$} \\
\hline 490.0166 & 490.0174 & $4\left[\mathrm{Fe}_{2} \mathrm{~L} 3\right]^{+\bullet}$ \\
\hline 537.1236 & 537.1246 & {$\left[\mathrm{FeL} 3\left(\mathrm{C}_{7} \mathrm{H}_{5} \mathrm{~N}\right)\right]^{+}$} \\
\hline 582.0424 & 582.0436 & {$\left[\mathrm{Fe}_{2} \mathrm{~L} 3\left(\mathrm{C}_{6} \mathrm{H}_{4} \mathrm{O}\right)\right]^{+}$} \\
\hline 614.1499 & 614.1512 & {$\left[\mathrm{FeL} 3\left(\mathrm{~L} 3-\mathrm{C}_{12} \mathrm{H}_{10} \mathrm{~N}_{2} \mathrm{O}\right)\right]^{+}$} \\
\hline 671.0933 & 671.0940 & {$\left[\mathrm{Fe}_{2} \mathrm{~L} 3\left(\mathrm{~L} 3-\mathrm{C}_{12} \mathrm{H}_{9} \mathrm{~N}_{2} \mathrm{O}\right)\right]^{+}$} \\
\hline 687.0878 & 687.0889 & {$\left[\mathrm{Fe}_{2} \mathrm{~L} 3\left(\mathrm{~L} 3-\mathrm{C}_{12} \mathrm{H}_{9} \mathrm{~N}_{2}\right)\right]^{+}$} \\
\hline 708.1915 & 708.1931 & {$\left[\mathrm{FeL} 3\left(\mathrm{~L} 3-\mathrm{C}_{6} \mathrm{H}_{4} \mathrm{~N}_{2}\right)\right]^{+}$} \\
\hline 764.1262 & 764.1281 & {$\left[\mathrm{Fe}_{2} \mathrm{~L} 3\left(\mathrm{~L} 3-\mathrm{C}_{6} \mathrm{H}_{4} \mathrm{~N}_{2}\right)\right]^{+}$} \\
\hline 868.1624 & 868.1656 & {$\left[\mathrm{Fe}_{2} \mathrm{~L}_{2}\right]^{+\bullet}$} \\
\hline
\end{tabular}

increased extent of cleavage within the ligand, as well as the singly-charged dinuclear double-stranded species $\left[\mathrm{Fe}_{2} \mathrm{~L}_{2}\right]^{+}$. Peaks corresponding to [FeL2(L2 $\left.\left.\mathrm{C}_{7} \mathrm{H}_{8} \mathrm{~N}_{2}\right)\right]^{+}$, [FeL2 $\left.\left(\mathrm{L} 2_{2}-\mathrm{C}_{7} \mathrm{H}_{6} \mathrm{~N}_{2}\right)\right]^{+}$, and $\left[\mathrm{Fe}_{2} \mathrm{~L} 2(\mathrm{~L} 2\right.$ $\left.\left.\mathrm{C}_{7} \mathrm{H}_{6} \mathrm{~N}_{2}\right)\right]^{+}$were observed. Figure $2 \mathrm{e}$ and $\mathrm{f}$ show the ECD mass spectra obtained from $\left[\mathrm{Fe}_{2} \mathrm{~L}_{3}\right]^{4+}$ ions. The results reflect those obtained from ligands L1 and L2 (see Table 1), with more extensive cleavage within the ligand observed. Peaks corresponding to $\left[\mathrm{Fe}_{2} \mathrm{~L}_{3}\right]^{3+}{ }^{\bullet}$, $\left[\mathrm{Fe}_{2} \mathrm{~L}_{2}\right]^{2+},\left[\mathrm{Fe}_{2} \mathrm{~L} 3\right]^{+}$, and $\left[\mathrm{Fe}_{2} \mathrm{~L}_{2}\right]^{+}$ions were observed. Product ions involving ligand backbone cleavage were $\left[\mathrm{FeL} 3\left(\mathrm{C}_{7} \mathrm{H}_{5} \mathrm{~N}\right)\right]^{+},\left[\mathrm{Fe}_{2} \mathrm{~L} 3\left(\mathrm{C}_{6} \mathrm{H}_{4} \mathrm{O}\right)\right]^{+}$, [FeL3( $\mathrm{L} 3-$ $\left.\left.\mathrm{C}_{12} \mathrm{H}_{10} \mathrm{~N}_{2} \mathrm{O}\right)\right]^{+}, \quad\left[\mathrm{Fe}_{2} \mathrm{~L} 3\left(\mathrm{~L} 3-\mathrm{C}_{12} \mathrm{H}_{9} \mathrm{~N}_{2} \mathrm{O}\right)\right]^{+}, \quad\left[\mathrm{Fe}_{2} \mathrm{~L} 3\right.$ $\left.\left(\mathrm{L} 3-\mathrm{C}_{12} \mathrm{H}_{9} \mathrm{~N}_{2}\right)\right]^{+}$, [FeL3 $\left.\left(\mathrm{L} 3-\mathrm{C}_{6} \mathrm{H}_{4} \mathrm{~N}_{2}\right)\right]^{+}$, and $\left[\mathrm{Fe}_{2} \mathrm{~L} 3\right.$ $\left.\left(\mathrm{L} 3-\mathrm{C}_{6} \mathrm{H}_{4} \mathrm{~N}_{2}\right)\right]^{+}$.

For all the di-iron triple helical species studied, initial electron capture by the $\mathrm{Fe}_{2} \mathrm{~L}_{3}{ }^{4+}$ complex results in the $\mathrm{Fe}_{2} \mathrm{~L}_{3}{ }^{3+} \cdot$. Electron capture could either occur at one of the $\mathrm{Fe}^{\mathrm{II}}$ centers to give $\mathrm{Fe}^{\mathrm{I}}$ or, given the presence of $\pi$-acceptor ligands, the additional electron may be located in a pyridylimine-based $\pi^{*}$ orbital or a mixed metal-ligand orbital. The complex remains triple-stranded. Further electron capture results in production of the dinuclear double-stranded species $\left[\mathrm{Fe}_{2} \mathrm{~L}_{2}\right]^{2+}$ in high yield. Clearly, the doubly-charged triple-stranded complex is not kinetically stable, and dissociates, expelling a 

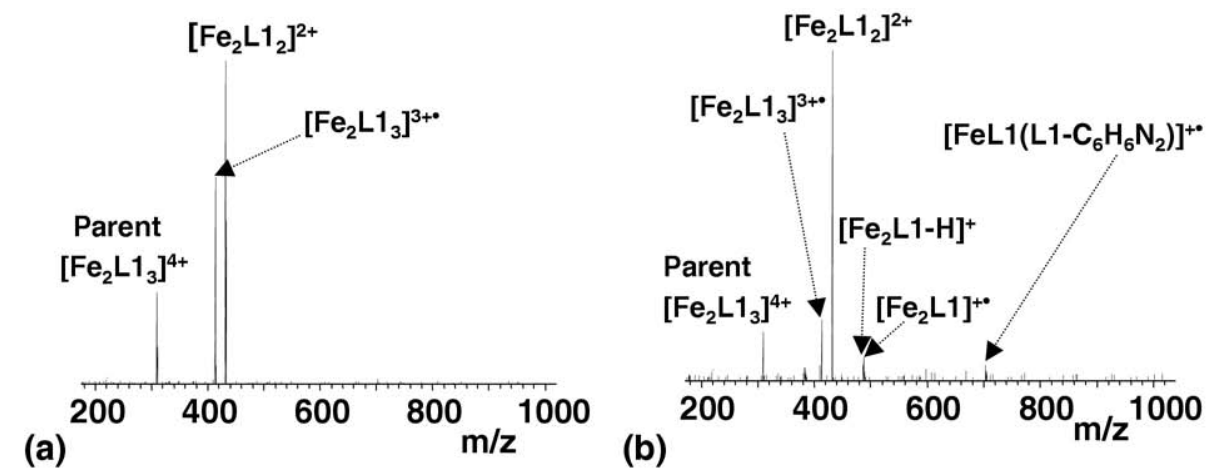

(b)
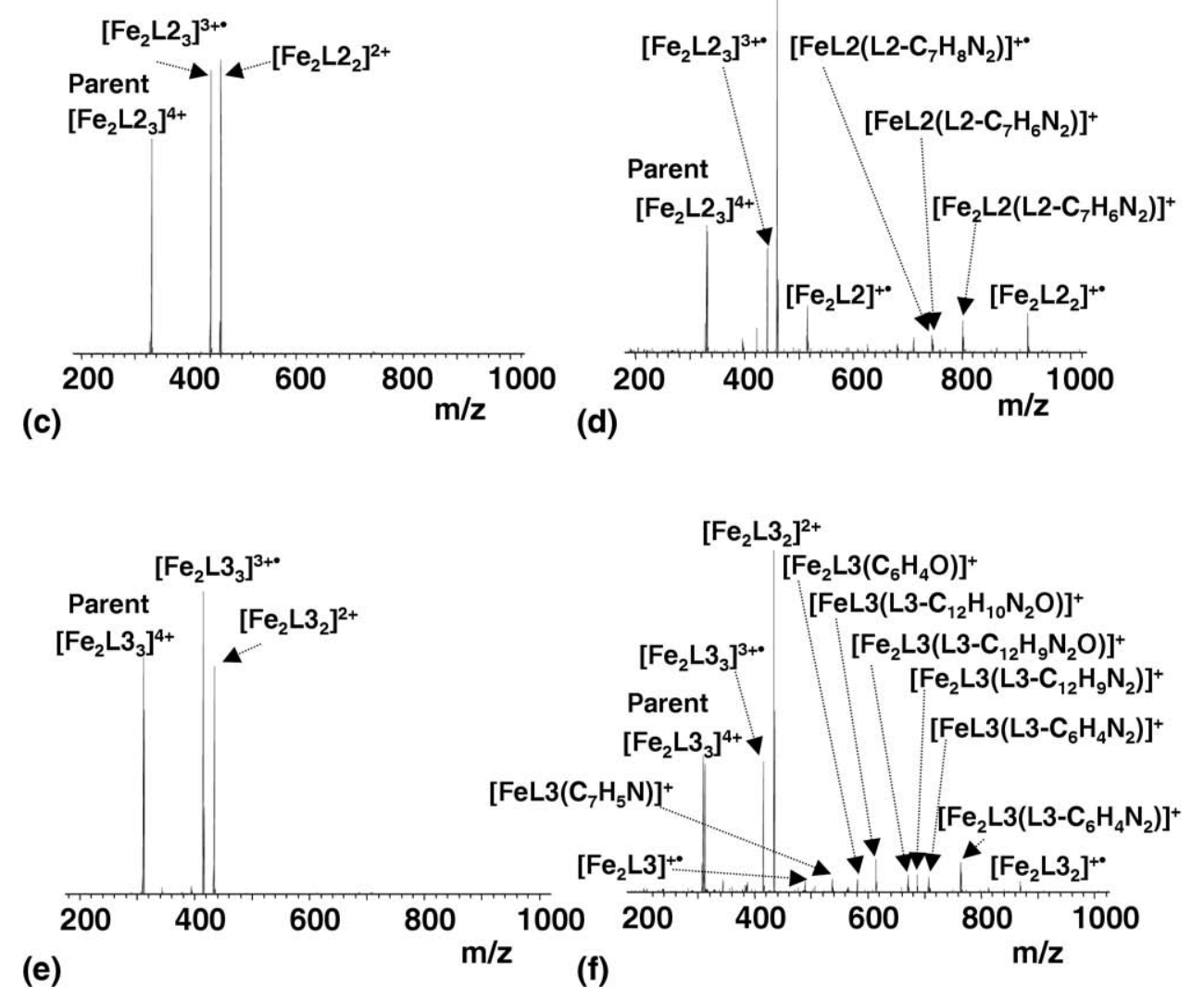

Figure 2. Electron capture dissociation mass spectra obtained following (a) $30 \mathrm{~ms}$ and (b) $70 \mathrm{~ms}$ irradiation of $\left[\mathrm{Fe}_{2} \mathrm{~L}_{3}\right]^{4+}$ precursor ions; following (c) $30 \mathrm{~ms}$ and (d) $100 \mathrm{~ms}$ irradiation of $\left[\mathrm{Fe}_{2} \mathrm{~L}_{3}\right]^{4+}$ precursor ions; and following (e) $30 \mathrm{~ms}$ and (f) $100 \mathrm{~ms}$ irradiation of $\left.\mathrm{Fe}_{2} \mathrm{~L}_{3}\right]^{4+}$ precursor ions. Fragment ions observed are detailed in Table 1.

ligand to give the dinuclear double-stranded complex. Iron(I) dinuclear double-stranded species $\left[\mathrm{M}_{2} \mathrm{~L}_{2}\right]^{2+}$ have not been isolated and studied in solution, however analogous species are observed in the condensed phase following reaction of the ligand with the stable metal monocations $\mathrm{Cu}^{\mathrm{I}}$ or $\mathrm{Ag}^{\mathrm{I}}$. Reducing the charge at the metal requires a lower coordination number to stabilize that charge.

Electron capture by the $\left[\mathrm{Fe}_{2} \mathrm{~L}_{2}\right]^{2+}$ cations results in either singly-charged double-stranded $\left[\mathrm{Fe}_{2} \mathrm{~L}_{2}\right]^{+}{ }^{\bullet}$, or singlycharged mono-stranded $\left[\mathrm{Fe}_{2} \mathrm{~L}\right]^{+} \cdot$. Electron capture by the $\left[\mathrm{Fe}_{2} \mathrm{~L}_{2}\right]^{2+}$ cations also results in cleavage within the ligand. (Ligand cleavage was previously observed following electron capture by lanthanide metal(III)ligand complexes and lanthanide metal(III)-ligandphosphopeptide complexes [26]). In the simplest case (ligand L1, Figure 2b), a peak corresponding to loss of $\mathrm{C}_{6} \mathrm{H}_{6} \mathrm{~N}_{2}$ is observed. The cleavage is demonstrated in Scheme 1, following the assumption that the dinuclear double-stranded species exists as $\mathrm{Fe}^{\mathrm{I}}, \mathrm{Fe}^{\mathrm{I}}$ and that electron capture occurs at the metal. It is postulated that addition of the electron to the doubly-charged di-iron dinuclear double-strand weakens ligand binding with subsequent hydrogen atom rearrangement. It is also 


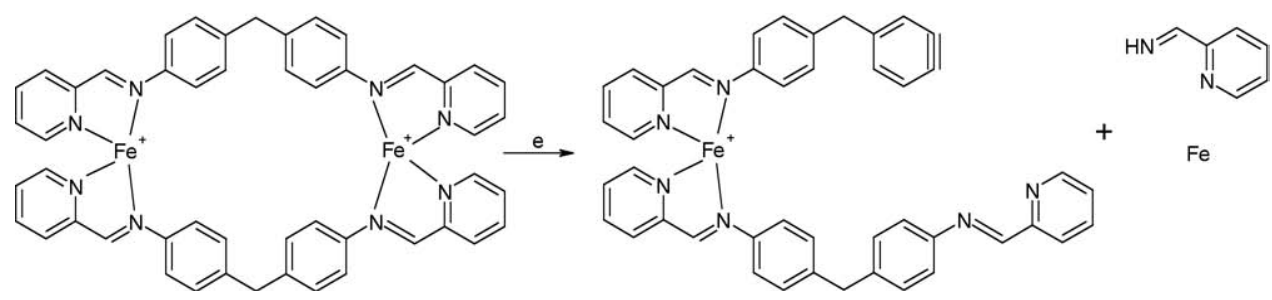

Scheme 1. Elimination of $\mathrm{C}_{6} \mathrm{H}_{6} \mathrm{~N}_{2}$ from $\left[\mathrm{Fe}_{2} \mathrm{L1}_{2}\right]^{2+}$ ions following electron capture.

possible that electron capture by the ligand occurs. (Note that Scheme $\mathbf{1}$ is a stylized representation and no inference regarding coordination structure should be drawn). The equivalent cleavage for ligand L2 is observed as a peak corresponding to [FeL2 $\left.\left(\mathrm{L} 2-\mathrm{C}_{7} \mathrm{H}_{8} \mathrm{~N}_{2}\right)\right]^{+}$ions, see Figure $2 \mathrm{~d}$ and Table 1. Also observed in this mass spectrum are peaks corresponding to $\left[\mathrm{Fe}_{\mathrm{n}} \mathrm{L} 2\left(\mathrm{~L} 2-\mathrm{C}_{7} \mathrm{H}_{6} \mathrm{~N}_{2}\right)\right]^{+\bullet}(n=1,2)$.

As a result of the central oxygen in the ligand backbone, cleavage within ligand L3 is more complex, see Scheme 2. Evidence for cleavage analogous to that shown in Scheme 1 arises through the presence of peaks corresponding to $\left[\mathrm{Fe}_{\mathrm{n}} \mathrm{L} 3\left(\mathrm{~L} 3-\mathrm{C}_{6} \mathrm{H}_{4} \mathrm{~N}_{2}\right)\right]^{+} \cdot(n=1,2)$. In this case, the cleavage does not involve hydrogen atom rearrangement, possibly resulting in the nitrile pyridine. Peaks corresponding to $\left[\mathrm{Fe}_{2} \mathrm{~L} 3\left(\mathrm{~L} 3-\mathrm{C}_{12} \mathrm{H}_{9} \mathrm{~N}_{2} \mathrm{O}\right)\right]^{+\cdot},\left[\mathrm{Fe}_{2} \mathrm{~L} 3(\mathrm{~L} 3-\right.$ $\left.\left.\mathrm{C}_{12} \mathrm{H}_{9} \mathrm{~N}_{2}\right)\right]^{+}$, and [FeL3(L3 $\left.\left.-\mathrm{C}_{12} \mathrm{H}_{10} \mathrm{~N}_{2} \mathrm{O}\right)\right]^{+}$ions are the result of cleavage of the aryl ether bond. Interestingly, the di-iron products do not involve hydrogen atom rearrangement within the ligand, unlike formation of the mono-iron product. Finally, peaks corresponding to $\left[\mathrm{Fe}_{2} \mathrm{~L} 3\left(\mathrm{C}_{6} \mathrm{H}_{4} \mathrm{O}\right)\right]^{+}$and $\left[\mathrm{FeL} 3\left(\mathrm{C}_{7} \mathrm{H}_{5} \mathrm{~N}\right)\right]^{+}$ions are observed. Formation of the $\left[\mathrm{Fe}_{2} \mathrm{~L} 3\left(\mathrm{C}_{6} \mathrm{H}_{4} \mathrm{O}\right)\right]^{+}$species occurs via cleavage of the aryl imine bond (see Scheme 1) and the aryl ether bond. Again, this di-iron product does not appear to involve hydrogen atom rearrangement. It is concluded that the $\mathrm{C}_{6} \mathrm{H}_{4} \mathrm{O}$ moiety is stabilized via $\pi$ stacking interactions with the phenylene rings of the intact ligand, which in turn is coordinated to the two Fe centers. Production of the $\left[\mathrm{FeL} 3\left(\mathrm{C}_{7} \mathrm{H}_{5} \mathrm{~N}\right)\right]^{+}$ ions is less clear. The fragmentation pathway either involves cleavage of the aryl ether together with the bond that connects the pyridine to the imine-carbon, or cleavage of the imine bond.

$\mathrm{MS}^{3}$ of $\mathrm{Fe}_{2} \mathrm{L1}_{2}{ }^{2+}$ and $\mathrm{MS} / \mathrm{MS}$ of $\mathrm{Cu}_{2} \mathrm{L1}_{2}{ }^{2+}$ and $\mathrm{Ag}_{2} \mathrm{L1}_{2}{ }^{2+}$ Complexes

Perhaps the most intriguing result of electron capture by the $\mathrm{Fe}_{2} \mathrm{~L}_{3}{ }^{4+}$ ions is the production of the dinuclear

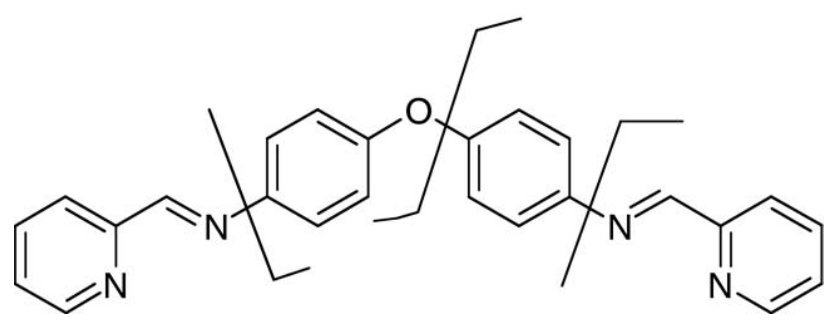

Scheme 2. Cleavage sites observed within ligand L3. double-stranded species $\mathrm{Fe}_{2} \mathrm{~L}_{2}{ }^{2+}$. Analogous species, $\mathrm{M}_{2} \mathrm{~L}_{2}{ }^{2+}$, are observed in solution for the monocations $\mathrm{Cu}^{\mathrm{I}}$ and $\mathrm{Ag}^{\mathrm{I}}$. The question arises: Are the iron-bound dimers of the form $\mathrm{Fe}_{2}{ }_{2} \mathrm{~L}_{2}{ }^{2+}$, i.e., has electron capture in the gas-phase resulted in an iron oxidation state that is not typically accessible in solution? To address this question, we compared the gas-phase behavior of the $\mathrm{Fe}_{2} \mathrm{L1}_{2}{ }^{2+}$ ions with that of $\mathrm{Ag}_{2} \mathrm{L1}_{2}{ }^{2+}$ and $\mathrm{Cu}_{2} \mathrm{L1}_{2}{ }^{2+}$ ions. The most abundant fragment ions observed following ECD, CID, and IRMPD of the $\mathrm{Ag}_{2} \mathrm{~L}_{2}{ }^{2+}, \mathrm{Cu}_{2} \mathrm{L1}_{2}{ }^{2+}$, and $\mathrm{Fe}_{2} \mathrm{L1}_{2}{ }^{2+}$ ions are detailed in Table 2 .

Figure 3 a shows the ECD mass spectrum of $\mathrm{Ag}_{2} \mathrm{L1}_{2}{ }^{2+}$ ions following $30 \mathrm{~ms}$ irradiation. No intact chargereduced dimeric species are observed. The major product is the metal-bound monomer $\mathrm{AgL1}^{+}$. Although the peak corresponding to $\mathrm{AgL1}^{+}$ions overlaps with that of the precursor $\mathrm{Ag}_{2} \mathrm{Ll}_{2}{ }^{2+}$ ions, the presence of the monomer can be confirmed by examination of the isotopic envelope, see Figure 3a inset top. The red diamonds indicate the theoretical distribution of the dimer, and the blue triangles indicate that of the monomer. It could be argued that monomer ions were amongst the dimers selected for ECD, i.e., were present either in the solution phase or in the gas phase before MS/MS. However, the isotopic envelope of the isolated ions, see Figure $3 \mathrm{a}$ inset (bottom), suggests that the silver complex is entirely, or mostly, dimeric before ECD. The second, and minor, product of ECD is $\mathrm{AgLl}_{2}{ }^{+}$. Presumably, that species is the result of electron capture by a silver cation. Similar behavior has been observed by us previously in the ECD of Ag-bound polyamidoamine (PAMAM) dendrimer complex [18].

In the CID and IRMPD of $\mathrm{Ag}_{2} \mathrm{L1}_{2}{ }^{2+}$ ions, three major fragmentation channels were observed. First, dissociation of the dinuclear dimer to the mononuclear monomer was observed. The presence of the Ag-bound monomer following IRMPD is confirmed by the distribution of the isotopic envelope (see Figure 3c, inset). The isotopic envelope following CID is somewhat skewed (Figure $3 \mathrm{~b}$, inset). As the CID products were detected in the ICR cell, it was necessary to accumulate a much larger number of precursor ions than ideal for optimal performance of the ion trap. That had the effect of altering the ion trajectories due to space-charge effects and, to isolate the precursor ions, it was necessary to center the isolation window on an $\mathrm{m} / \mathrm{z}$ value, which did not correspond to that of the precursors (by $\sim 1 \mathrm{Th}$ ). However, the experimental parameters for CID are calculated by the software on the basis of the 


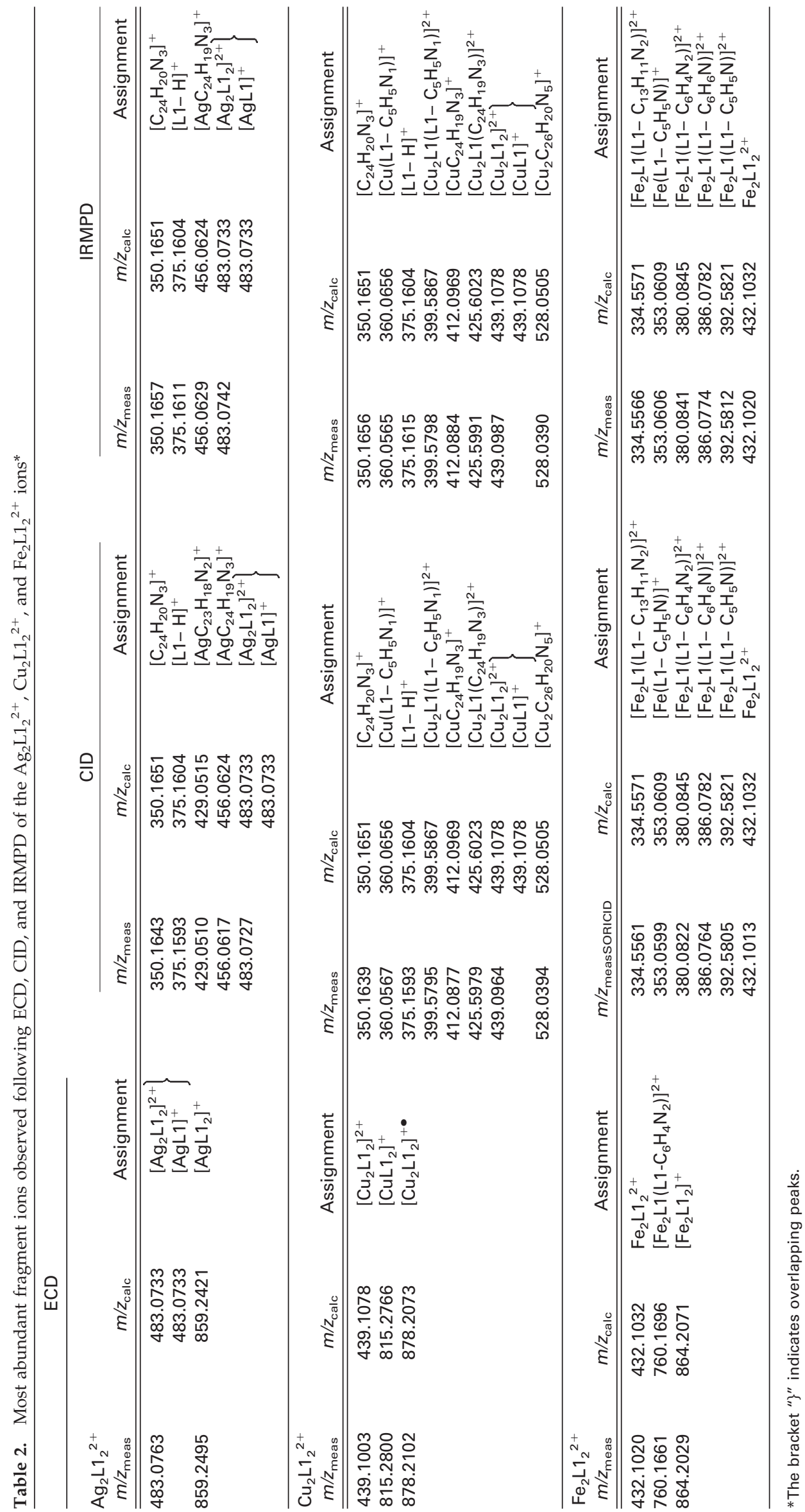




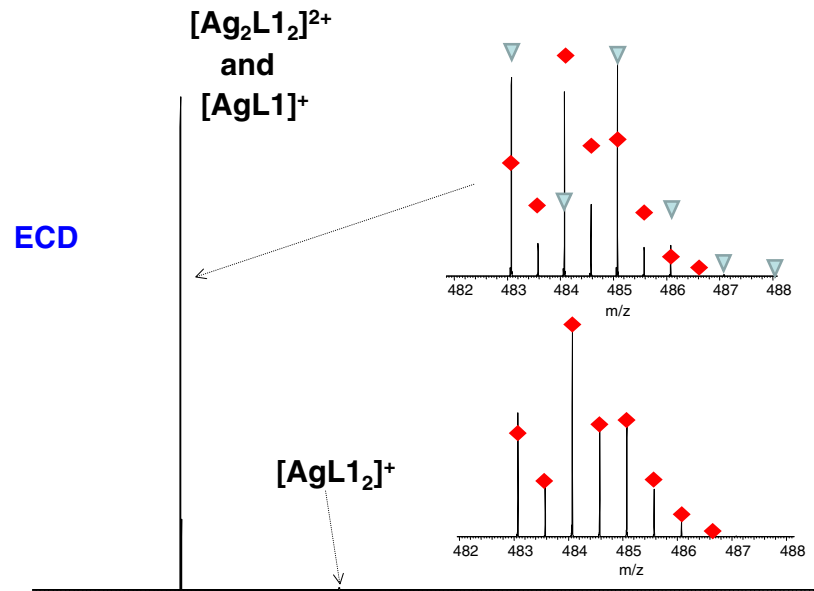

(a)

$200400600 \quad 800 \quad 10001200140016001800$

$\mathrm{m} / \mathbf{z}$

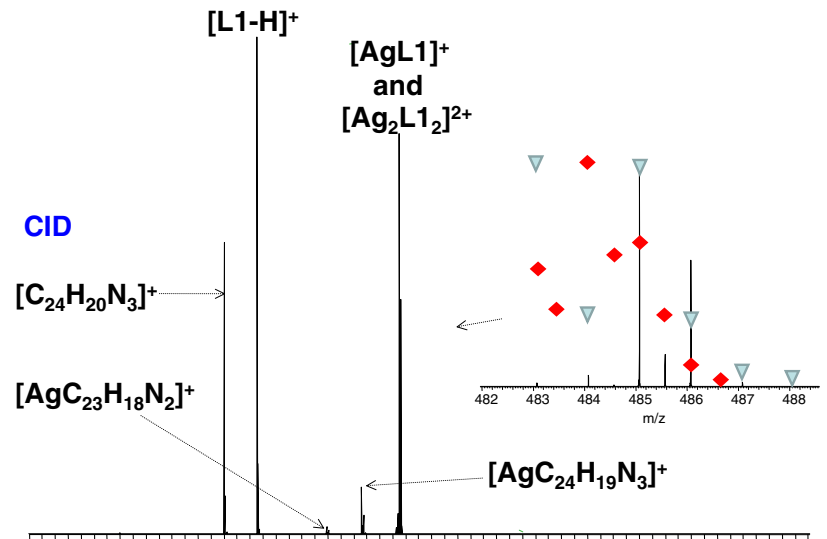

$200250300 \quad 350400450500550600650700750$

(b) $\mathrm{m} / \mathbf{z}$

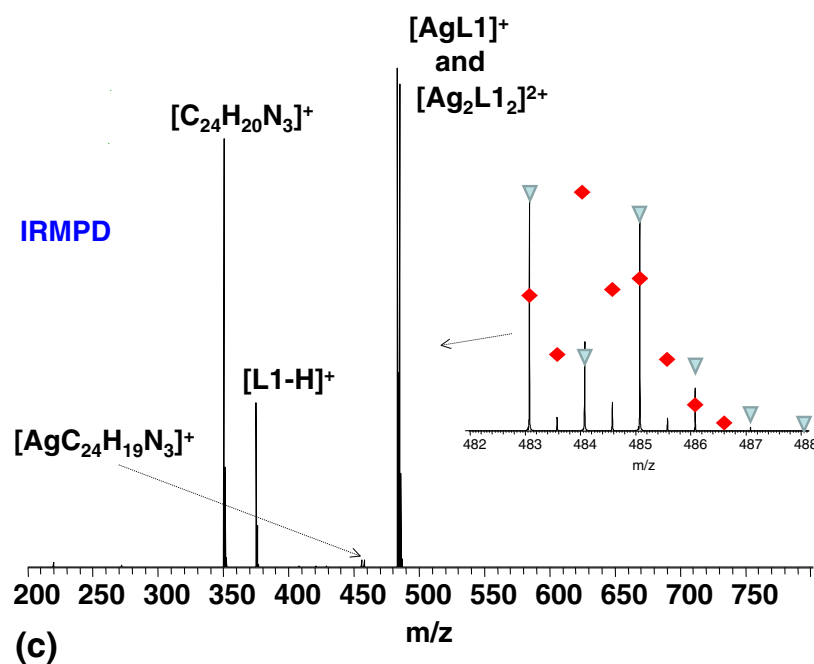

Figure 3. (a) ECD mass spectrum of $\left[\mathrm{Ag}_{2} \mathrm{L1}_{2}\right]^{2+}$ ions; (b) CID mass spectrum of $\left[\mathrm{Ag}_{2} \mathrm{~L}_{2}\right]^{2+}$ ions; (c) IRMPD mass spectrum of $\left[\mathrm{Ag}_{2} \mathrm{L1}_{2}\right]^{2+}$ ions.

user-defined precursor isolation $\mathrm{m} / \mathrm{z}$ value. Hence, a distorted isotopic envelope is observed. Nevertheless, apparently the Ag-bound monomer is formed. Second, a peak corresponding to $[\mathrm{L} 1-\mathrm{H}]^{+}$ions was observed. The loss of $\mathrm{AgH}$, via hydride abstraction, following CID of $\mathrm{Ag}^{+}$complexes of primary and tertiary amines, $\alpha$-amino acids, amino carboxylic acids, aryl alkyl ethers, and peptides is well-documented. Mass spectrometry experiments combined with density functional theory (DFT) calculations showed that for argentinated amines, hydrogen atom attached to the carbon $\alpha$ to the amino nitrogen is cleaved together with the $\mathrm{Ag}$ atom in a 1,2-elimination [36, 37]. It is postulated that the [L1 $\mathrm{H}]^{+}$product ions observed here are the result of dissociation of the Ag-bound monomer. The third fragmentation pathway involves loss of cyanide from the ligand. Peaks corresponding to $\left[\mathrm{C}_{24} \mathrm{H}_{20} \mathrm{~N}_{3}\right]^{+}$and $\left[\mathrm{AgC}_{24} \mathrm{H}_{19} \mathrm{~N}_{3}\right]^{+}$ were observed. Presumably, these fragments are the result of decomposition of the mononuclear monomer. Suggested mechanisms for the loss of HCN and AgCN from the Ag-bound monomer are shown in Scheme 3.

Figure $4 \mathrm{a}$ shows the ECD mass spectrum obtained following $30 \mathrm{~ms}$ irradiation of $\mathrm{Cu}_{2} \mathrm{L1}_{2}{ }^{2+}$ ions. The major product is the charge-reduced species $\mathrm{Cu}_{2} \mathrm{Ll}_{2}{ }^{+}$(see Table 2). Examination of the $m / z$ region around the precursor ions (Figure 4a, inset top) suggests that, unlike the silver species, monomeric $\mathrm{CuL1}^{+}$is not a major product of electron capture. The precursor $\mathrm{m} / \mathrm{z}$ region post-ECD reflects the isotopic envelope of the precursor peak following isolation (Figure 4a, inset bottom). In addition to the charge-reduced species, a very low abundance peak corresponding to $\mathrm{CuL1}_{2}{ }^{+}$ was observed. The analogous fragment was observed following ECD of the silver-bound dimer. Formation of $\mathrm{CuL}_{2}{ }^{+}$must be the result of electron capture by $\mathrm{Cu}^{+}$ and subsequent loss of the copper atom.

As seen for $\left[\mathrm{Ag}_{2} \mathrm{~L}_{2}\right]^{2+}, \mathrm{CID}$ and IRMPD of $\left[\mathrm{Cu}_{2} \mathrm{~L}_{2}\right]^{2+}$ ions results in dissociation of dinuclear dimer to mononuclear monomer $[\mathrm{CuL} 1]^{+}$, production of $[\mathrm{L} 1-\mathrm{H}]^{+}$, and loss of cyanide from the ligand. The distribution of the isotopic envelope shown in Figure 4c (inset) confirms the presence of $\mathrm{Cu}$-bound monomer following IRMPD. The isotopic envelope following CID is again skewed-a consequence of space-charge effects in the linear ion trap-(Figure $4 \mathrm{~b}$, inset), however the results suggest that the monomer is formed. The $[\mathrm{L} 1-\mathrm{H}]^{+}$ product ions observed in both CID and IRMPD are the result of the loss of $\mathrm{CuH}$ from $\mathrm{Cu}$-bound monomer. The peaks corresponding to $\left[\mathrm{C}_{24} \mathrm{H}_{20} \mathrm{~N}_{3}\right]^{+}$ions indicate loss of $\mathrm{CuCN}$ from mononuclear $[\mathrm{CuL} 1]^{+}$, and those corresponding to $\left[\mathrm{CuC}_{24} \mathrm{H}_{19} \mathrm{~N}_{3}\right]^{+}$ions indicate loss of $\mathrm{HCN}$. Both processes, i.e., loss of $\mathrm{HCN}$ and loss of $\mathrm{CuCN}$, must proceed via intramolecular rearrangements, similar to those for the Ag-bound monomer (Scheme $\mathbf{3 a}$ and $\mathbf{b}$ ).

The CID and IRMPD MS/MS spectra obtained for $\left[\mathrm{Cu}_{2} \mathrm{L1}_{2}\right]^{2+}$ ions also show fragmentation pathways that were not observed for $\left[\mathrm{Ag}_{2} \mathrm{Ll}_{2}\right]^{2+}$ ions (see Table 2). Peaks corresponding to singly-charged $\left[\mathrm{Cu}\left(\mathrm{L} 1-\mathrm{C}_{5} \mathrm{H}_{5} \mathrm{~N}_{1}\right)\right]^{+}$ and doubly-charged $\left[\mathrm{Cu}_{2} \mathrm{~L} 1\left(\mathrm{~L} 1-\mathrm{C}_{5} \mathrm{H}_{5} \mathrm{~N}_{1}\right)\right]^{2+}$ ions are the result of the loss of pyridine from the ligands of the mononuclear monomer and the dinuclear dimer respectively. The peaks corresponding to $\left[\mathrm{Cu}_{2} \mathrm{C}_{26} \mathrm{H}_{20} \mathrm{~N}_{5}\right]^{+}$, 

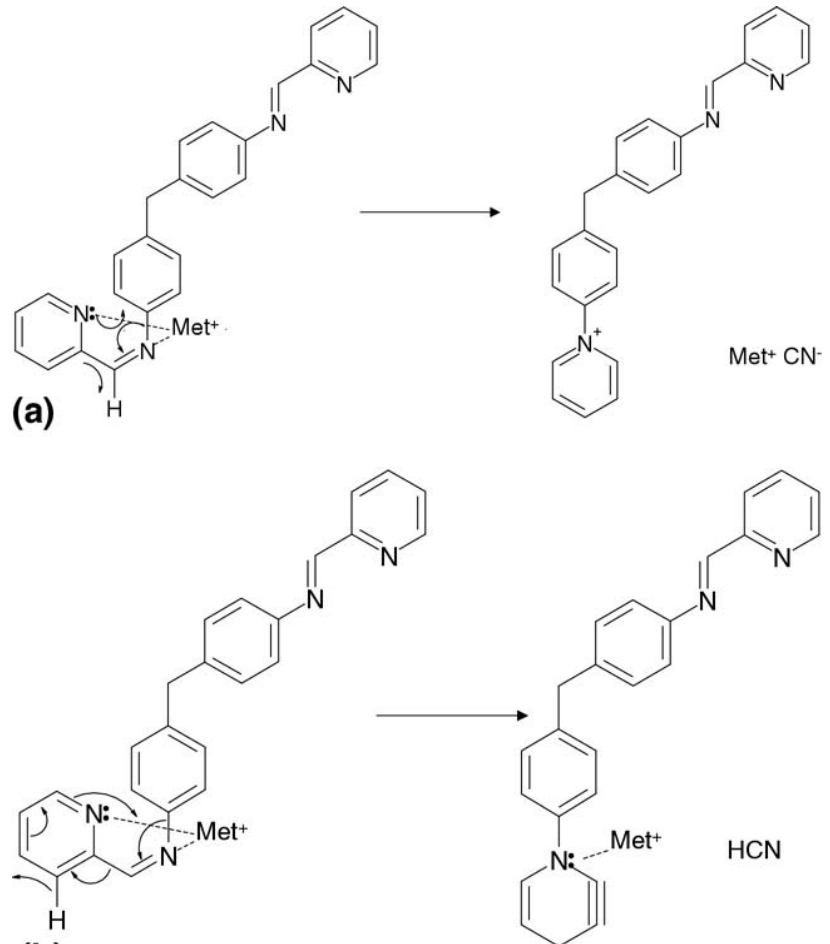

(b)

Scheme 3. Suggested mechanism for cleavage and rearrangement leading to loss of: (a) $\mathrm{HCN}$; (b) MetCN from [MetL1] ${ }^{+}$ions, where Met $=\mathrm{Ag}^{+}$and $\mathrm{Cu}^{+}$.

which can also be depicted as $\left[\mathrm{CuL} 1+\mathrm{CuCN}^{+}\right.$, suggest that dissociation of dinuclear dimer to mononuclear monomer is accompanied by decomposition of one of the mononuclear monomers. $\mathrm{CuCN}$ lost from one of the monomers is retained with the second. The peaks corresponding to $\left[\mathrm{Cu}_{2} \mathrm{~L} 1\left(\mathrm{C}_{24} \mathrm{H}_{19} \mathrm{~N}_{3}\right)\right]^{2+}$ indicate loss of $\mathrm{HCN}$ from doubly-charged dinuclear dimer ions. Again, that process was not observed in the case of CID and IRMPD of the silver-bound dinuclear dimer.

Figure $5 \mathrm{a}$ shows the ECD MS ${ }^{3}$ mass spectrum of $\left[\mathrm{Fe}_{2} \mathrm{~L}_{2}\right]^{2+}$ ions following $25 \mathrm{~ms}$ irradiation. The singlycharged mononuclear monomer does not appear to be formed (see Figure $5 \mathrm{a}$, inset). The major product is the charge-reduced species $\left[\mathrm{Fe}_{2} \mathrm{~L}_{2}\right]^{+}$. The equivalent product was observed following ECD of the copper dimer but not the silver dimer. A peak corresponding to doubly-charged $\left[\mathrm{Fe}_{2} \mathrm{~L} 1\left(\mathrm{~L} 1-\mathrm{C}_{6} \mathrm{H}_{4} \mathrm{~N}_{2}\right)\right]^{2+}$ ions was also observed in the ECD MS ${ }^{3}$ spectrum. That peak was also observed in the ECD of the di-iron triple helicate following extended irradiation. The equivalent peak was not observed following ECD of either the copperand silver-bound dimers.

The SORI-CID and IRMPD MS ${ }^{3}$ spectra obtained for the ECD-derived $\left[\mathrm{Fe}_{2} \mathrm{L1}_{2}\right]^{2+}$ ions (shown in Figure $5 \mathrm{~b}$ and c) are dominated by fragments formed as a result of cleavages within the ligand (see Table 2). Peaks corresponding to loss of a $\mathrm{C}_{5} \mathrm{H}_{5} \mathrm{~N}$ ring from doubly-charged dinuclear dimers and singly-charged mononuclear monomers were observed: $\left[\mathrm{Fe}_{2} \mathrm{~L} 1\left(\mathrm{~L} 1-\mathrm{C}_{5} \mathrm{H}_{5} \mathrm{~N}\right)\right]^{2+}$ and $\left[\mathrm{Fe}\left(\mathrm{L} 1-\mathrm{C}_{5} \mathrm{H}_{5} \mathrm{~N}\right)\right]^{+}$, respectively. Similar fragmentation behavior was observed following CID and IRMPD of the copper-bound dimers but not the silverbound dimers. Singly-charged $\left[\mathrm{Fe}_{2} \mathrm{~L} 1\left(\mathrm{~L} 1-\mathrm{C}_{5} \mathrm{H}_{5} \mathrm{~N}\right)\right]^{+}$
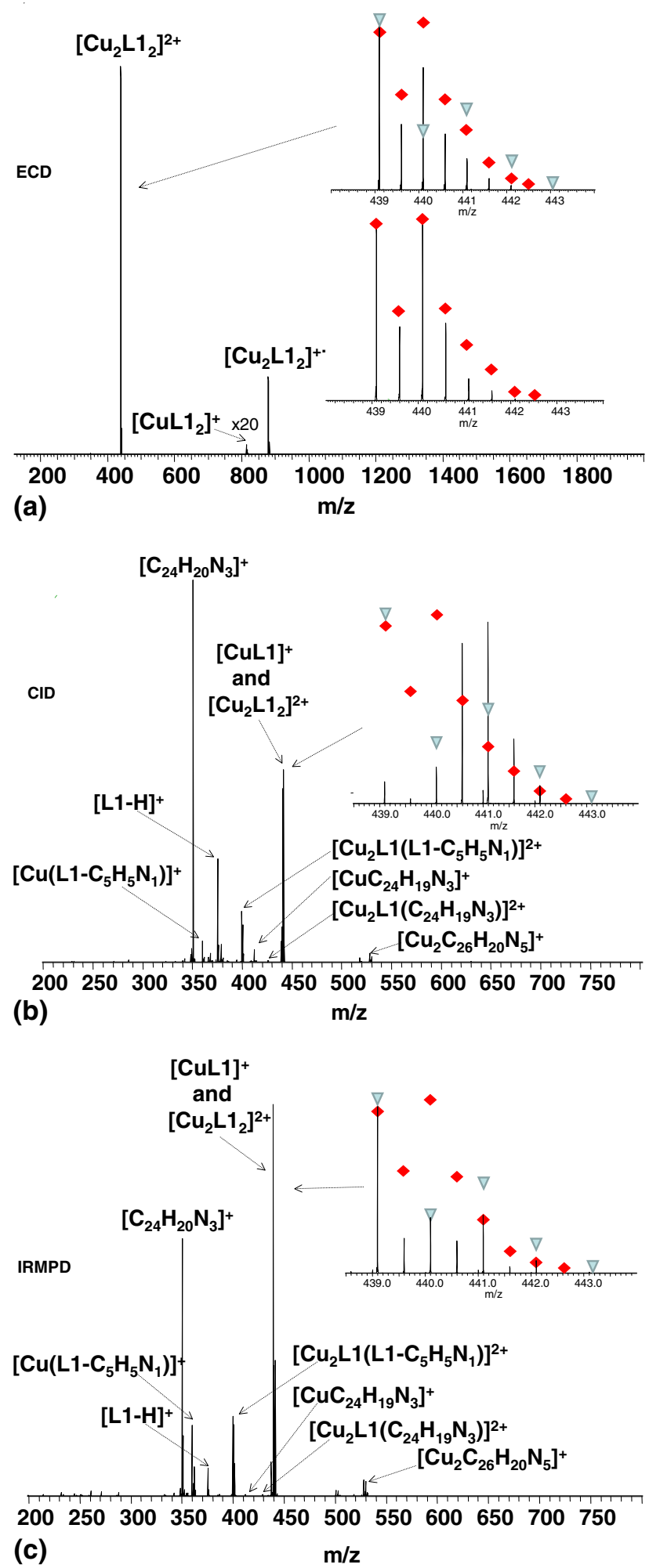

Figure 4. (a) ECD mass spectrum of $\left[\mathrm{Cu}_{2} \mathrm{~L}_{2}\right]^{2+}$ ions; (b) CID mass spectrum of $\left[\mathrm{Cu}_{2} \mathrm{L1}_{2}\right]^{2+}$ ions; (c) IRMPD mass spectrum of $\left[\mathrm{Cu}_{2} \mathrm{~L}_{2}\right]^{2+}$ ions. 


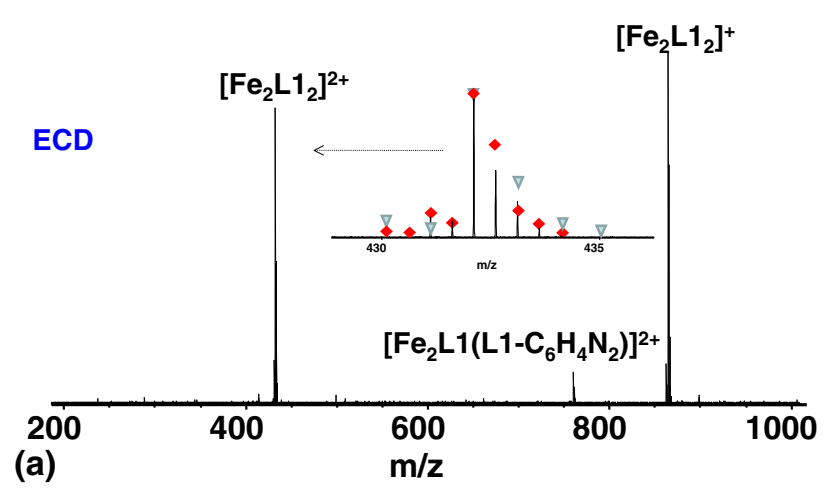

$\left[\mathrm{Fe}_{2} \mathrm{~L} 1\left(\mathrm{~L} 1-\mathrm{C}_{5} \mathrm{H}_{5} \mathrm{~N}\right)\right]^{2+}$

IRMPD

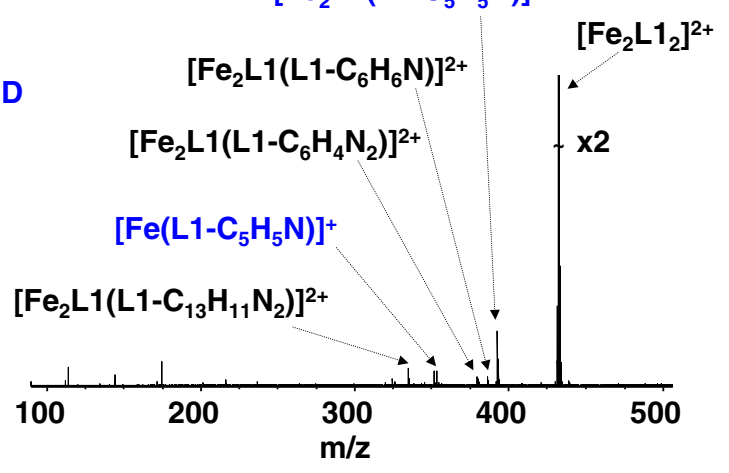

(b)

$\left[\mathrm{Fe}_{2} \mathrm{~L} 1\left(\mathrm{~L} 1-\mathrm{C}_{5} \mathrm{H}_{5} \mathrm{~N}\right)\right]^{2+}$

SORI-CID

(c)

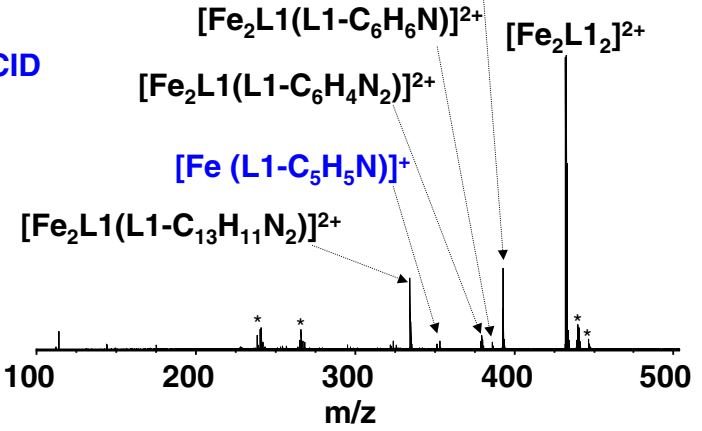

Figure 5. (a) ECD MS $\mathrm{S}^{3}$ spectra of $\left[\mathrm{Fe}_{2} \mathrm{L1}_{2}\right]^{2+}$ ions; (b) $\mathrm{CID} \mathrm{MS}^{3}$ spectra of $\left[\mathrm{Fe}_{2} \mathrm{L1}_{2}\right]^{2+}$ ions; (c) IRMPD MS ${ }^{3}$ spectra of $\left[\mathrm{Fe}_{2} \mathrm{L1}_{2}\right]^{2+}$ ions.

ions must the result of dissociation of dinuclear dimer to mononuclear monomer, a fragmentation process that was previously observed for both $\left[\mathrm{Ag}_{2} \mathrm{L1}_{2}\right]^{2+}$ and $\left[\mathrm{Cu}_{2} \mathrm{~L}_{2}\right]^{2+}$ ions; however, unlike those species, the intact mononuclear monomer was not observed. Other observed product ions involving ligand cleavage were $\left[\mathrm{Fe}_{2} \mathrm{~L} 1\left(\mathrm{~L} 1-\mathrm{C}_{13} \mathrm{H}_{11} \mathrm{~N}_{2}\right)\right]^{2+},\left[\mathrm{Fe}_{2} \mathrm{~L} 1\left(\mathrm{~L} 1-\mathrm{C}_{6} \mathrm{H}_{4} \mathrm{~N}_{2}\right)\right]^{2+}$, and $\left[\mathrm{Fe}_{2} \mathrm{~L} 1\left(\mathrm{~L} 1-\mathrm{C}_{6} \mathrm{H}_{6} \mathrm{~N}\right)\right]^{2+}$.

The fragmentation behavior of the ECD-derived doubly-charged dinuclear double-stranded $\left[\mathrm{Fe}_{2} \mathrm{~L}_{2}\right]^{2+}$ ions showed some similarities to that observed for the $\left[\mathrm{Cu}_{2} \mathrm{~L}_{2}\right]^{2+}$ ions but not the $\left[\mathrm{Ag}_{2} \mathrm{L1}_{2}\right]^{2+}$ ions. Fragmentation of $\left[\mathrm{Cu}_{2} \mathrm{L1}_{2}\right]^{2+}$ ions showed some similarities with both the iron-bound dimers and the silver-bound dimers. ECD of the iron and copper complexes resulted in the charge-reduced species but those species were not observed for the silver complex. ECD of the silverbound and copper-bound dimers resulted in singlycharged $\left[\mathrm{AgL1}_{2}\right]^{+}$and $\left[\mathrm{CuL}_{2}\right]^{+}$fragments. Those products must be the result of electron capture by, and subsequent loss of, the metal ion. $\left[\mathrm{FeL}_{2}\right]^{+}$ions were not observed following ECD. ECD of the iron-bound dimer also resulted in cleavage within the ligand. That was not observed for the silver and copper complexes. The SORI-CID and IRMPD of the $\left[\mathrm{Fe}_{2} \mathrm{~L}_{2}\right]^{2+}$ ions in SORICID and IRMPD experiments showed some similarities to the CID and IRMPD of the copper complex (i.e., loss of $\mathrm{C}_{5} \mathrm{H}_{5} \mathrm{~N}$ ring from the ligand, see Figure $4 \mathrm{~b}$ and $\mathrm{c}$, Figure $5 b$ and $c)$. The $\left[\mathrm{Fe}_{2} \mathrm{L1}_{2}\right]^{2+}$ ions also exhibited unique ligand cleavage (Figure $5 \mathrm{~b}$ and $\mathrm{c}$ ). The CID and IRMPD of the $\left[\mathrm{Ag}_{2} \mathrm{L1}_{2}\right]^{2+}$ ions reflected that of the $\left[\mathrm{Cu}_{2} \mathrm{L1}_{2}\right]^{2+}$ ions but not the $\left[\mathrm{Fe}_{2} \mathrm{L1}_{2}\right]^{2+}$ ions.

The differences in the observed fragmentation behavior of $\left[\mathrm{Fe}_{2} \mathrm{Ll}_{2}\right]^{2+},\left[\mathrm{Cu}_{2} \mathrm{L1}_{2}\right]^{2+}$, and $\left[\mathrm{Ag}_{2} \mathrm{L1}_{2}\right]^{2+}$ ions in ECD, CID, and IRMPD appear to track with the first ionization energies of the metal ions $\left(\mathrm{IE} 1_{\mathrm{Ag}} 7.57 \mathrm{eV}\right.$, $\left.\mathrm{IE} 1_{\mathrm{Cu}} 7.73 \mathrm{eV}, \mathrm{IE} 1_{\mathrm{Fe}} 7,90 \mathrm{eV}\right)$. For example, electron capture by the di-iron dimer results in the chargereduced species in high yield; by the di-copper dimer results in the charge-reduced species in lower yield, and the mononuclear monomer; and by the di-silver dimer results in the mononuclear monomer only. This conclusion is supported by our previous work on metal ion complexes of polyamidoamine (PAMAM) dendrimers [18], which showed that their ECD and CID behavior were dependent on the ionization energy, valence electrons, and charge of the metal ions. Studies on the ECD of peptide [22, 26] and lipid complexes [24] have also shown that the nature of metal ion dictates dissociation pathways.

\section{Conclusion}

The results shown constitute the first application of electron capture dissociation to supramolecular structure determination. The ECD mass spectra are straightforward to interpret, and information regarding stoichiometry and/or ligand structure can be obtained through variation of electron irradiation time. Of particular interest was the observation that the gas-phase structure of the $\mathrm{Fe}^{\mathrm{I}}$ supramolecular helicates mimicked that of the equivalent solution phase $\mathrm{Cu}^{\mathrm{I}}$ and $\mathrm{Ag}^{\mathrm{I}}$ complexes, i.e., they exist as dinuclear double-stranded species. Comparison of ECD, CID, and IRMPD fragmentation behavior of doubly charged di-iron dinuclear dimer ions with that observed for $\left[\mathrm{Cu}_{2} \mathrm{L1}_{2}\right]^{2+}$ and $\left[\mathrm{Ag}_{2} \mathrm{L1}_{2}\right]^{2+}$ reveal some similarities. Perhaps the most exciting conclusion is that electron capture by gas-phase metal complex cations may allow access to oxidation states that are not readily available in solution. Rather than existing solely as an analytical technique, ECD may be used as a source for previously unknown metallo-supramolecules, and their intrinsic gas-phase chemistry may be studied. 


\section{Acknowledgments}

The authors thank Professor Alan G Marshall, Dr. Chris L. Hendrickson, and Dr. Nathan Kaiser for providing access to the FT-ICR facility at the National High Magnetic Field Laboratory, Florida State University, and for technical assistance. The Wellcome Trust (074131) (H.J.C.), EPSRC (H.J.C. and M.A.K.), and the EU (A.H.) Marie Curie fellowship MEIF-CT-2005-024 024818) are acknowledged for funding. The authors acknowledge support in part for this work by NSF Division of Materials Research through DMR-06-54,118, and the State of Florida.

\section{References}

1. Baytekin, B.; Baytekin, T.; Schalley, C. A. Mass Spectrometric Studies of Noncovalent Compounds: Why Supramolecular Chemistry in the Gas Phase? Org. Biomol. Chem. 2006, 4, 2825-2841.

2. Sakamto, S.; Yoshizawa, M.; Kusukawa, T.; Fujita, M.; Yamaguchi, K. Characterization of Encapsulating Supramolecular by Using CSI-MS with Ionization-Promoting Reagents. Org. Lett. 2001, 3(11), 1601-1604.

3. Barbara, J. E.; Eyler, J. R.; Powell, D. H. Reactive Desorption Electrospray Ionization for Rapid Screening of Guests for Supramolecular Inclusion Complexes. Rapid Commun. Mass Spectrom. 2008, 22, 41214128.

4. Schalley, C. A.; Ghosh, P.; Engeser, M. Mass Spectrometric Evidence for Catenanes and Rotaxanes from Negative-ESI FT-ICR Tandem-MS Experiments. Int. J. Mass Spectrom. 2004, 232, 249-258.

5. Engeser, M.; Rang, A.; Ferrer, M.; Gutierrez, A.; Baytekin, H. T.; Schalley, C. A. Reactivity of Self-Assembled Supramolecular Complexes in the Gas Phase: A Supramolecular Neighbor Group Effect. Int. J. Mass Spectrom. 2006, 255, 185-194.

6. Schafer, M.; Schmuck, C.; Heil, M.; Cooper, H. J.; Hendrickson, C. L.; Chalmers, M. J.; Marshall, A. G. Determination of the Activation Energy for Unimolecular Dissociation of a Noncovalent Gas-Phase Peptide: Substrate Complex by Infrared Multiphoton Dissociation Fourier Transform Ion Cyclotron Resonance Mass Spectrometry. J. Am. Soc. Mass Spectrom. 2003, 17(11), 1282-1289.

7. Brusilowskij, B.; Neubacher, S.; Schalley, C. A. A Double Intramolecular Cage Contraction Within a Self-Assembled Metallo-Supramolecular Bowl. Chem. Commun. 2009, 785-787.

8. Schnier, P. D.; Klassen, J. S.; Strittmatter, E. E.; Williams, E. R. Activation Energies for Dissociation of Double Strand Oligonucleotides Anions: Evidence for Watson-Crick Pairing In Vacuo. J. Am. Chem. Soc. 1998, 120(37), 9605-9613.

9. Zubarev, R. A.; Kelleher, N. L.; McLafferty, F. W. ECD of Multiply Charged Protein Cations. A Nonergodic Process. J. Am. Chem. Soc. 1998, 120, 3265-3266

10. Cooper, H. J.; Hakansson, K.; Marshall, A. G. The Role of Electron Capture Dissociation in Biomolecular Analysis. Mass Spectrom. Rev. 2005, 24, 201-222.

11. Tsybin, Y. O.; Hakansson, P.; Budnik, B. A.; Haselmann, K. F.; Kjeldsen, F.; Gorshkov, M.; Zubarev, R. A. Improved Low-energy Electron Injection Systems for High Rate Electron Capture Dissociation in Fourier Transform Ion Cyclotron Resonance Mass Spectrometry. Rapid Commun. Mass Spectrom. 2001, 15, 1849-1854.

12. Marshall, A. G.; Hendrickson, C. L.; Jackson, G. S. Fourier Transform Ion Cyclotron Resonance Mass Spectrometry: A Primer. Mass Spectrom. Rev. 1998, 17, 1-35.

13. Cerda, B. A.; Horn, D. M.; Breuker, K.; Carpenter, B. K.; McLafferty, F. W. Electron Capture Dissociation of Multiply-Charged Oxygenated Cations. A Nonergodic Process. Eur. Mass Spectrom. 1999, 5, 335-338.

14. Cerda, B.; Breuker, K.; Horn, D. M.; McLafferty, F. W. Charge/Radical Site Initiation Versus Coulombic Repulsion for Cleavage of Multiply Charged Ions. Charge Solvation in Poly(Alkene Glycol) Ions. J. Am. Soc. Mass Spectrom. 2001, 12, 565-570.

15. Cerda, B. A.; Horn, D. M.; Breuker, K.; McLafferty, F. W. Sequencing of Specific Copolymer Oligomers by Electron-Capture-Dissociation Mass Spectrometry. J. Am. Chem. Soc. 2002, 124, 9287-9291.

16. Lee, S.; Han, S. Y.; Lee, T. G.; Chung, G.; Lee, D.; Oh, H. B. Observation of Pronounced b-Dot, y Cleavages in the ECD Mass Spectrometry of PAMAM Dendrimer Ions with Amide Functionalities. J. Am. Soc. Mass Spectrom. 2006, 17, 536-543.
17. Kaczorowska, M. A.; Cooper, H. J. ECD, EDD, and CID of PAMAM Dendrimer Ions with Amino, Amidoethanol, and Sodium Carboxylate Surface Groups. J. Am. Soc. Mass Spectrom. 2008, 19, 1312-1319.

18. Kaczorowska, M. A.; Cooper, H. J. Electron Capture Dissociation and Collision-Induced Dissociation of Metal Ion $[\mathrm{Ag}(+), \mathrm{Cu}(2+), \mathrm{Zn}(2+)$ $\mathrm{Fe}(2+)$, and $\mathrm{Fe}(3+)]$ Complexes of Polyamidoamine (PAMAM) Dendrimers. J. Am. Soc. Mass Spectrom. 2009, 20(4), 674-681.

19. Kaczorowska, M. A.; Cooper, H. J. Characterization of Polyphosphoesters by FT-ICR Mass Spectrometry. J. Am. Soc. Mass Spectrom. 2009, 20, 2238-2247.

20. Turecek, F.; Jones, J. W.; Holm, A. I. S.; Panja, S.; Nielsen, S. B. Hvelplund, P. Transition Metals as Electron Traps. I. Structures, Energetics, Electron Capture, and Electron-Transfer-Induced Dissociations of Ternary Copper-Peptide Complexes in the Gas Phase. J. Mass Spectrom. 2009, 44(5), 707-724.

21. Fung, Y. M. E.; Liu, H. C.; Chan, T.-W.D. ECD of Peptides Metallated with Alkaline Earth Metal Ions. J. Am. Soc. Mass Spectrom. 2006, 17(6), 757-771.

22. Liu, H.; Hakansson, K. Divalent Metal Ion-Peptide Interactions Probed by Electron Capture Dissociation of Trications. J. Am. Soc. Mass Spectrom. 2006, 17, 1731-1741.

23. Kleinnijenhuis, A. J.; Mihalca, R.; Heeren, R. M. A.; Heck, A. J. R. Atypical Behavior in the Electron Capture Induced Dissociation of Biologically Relevant Transition Metal Complexes of the Peptide Hormone Oxytocin. Int. J. Mass Spectrom. 2006, 253(3), 31-38.

24. James, P. F.; Perugini, M. A.; O'Hair, R. A. J. Electron Capture Dissociation of Complexes of Diacylglycerophosphocholine and Divalent Metal Ions: Competition Between Charge Reduction and Radical Induced Phospholipid Fragmentation. J. Am. Soc. Mass Spectrom. 2008, 19(7), 978-986.

25. Wu, B.; Duncombe, B. J.; Stace, A. J. Fragmentation Pathways of $[(\mathrm{Mg}(\mathrm{NH} 3) \mathrm{n}] 2+$ Complexes: Electron Capture Versus Charge Separation. J. Phys. Chem. A 2006, 110(27), 8423-8432.

26. Mosely, J. A.; Murray, B. S.; Parker, D. ECD and CID of Lanthanide Metal-Ligand Complexes and Lanthanide Metal-Ligand Complexes Bound to Phosphopeptides. Eur. J. Mass Spectrom. 2009, 15(2), 145-155.

27. Hannon, M. J.; Painting, C. L.; Jackson, A. J.; Hamblin, J.; Errington, W. An Inexpensive Approach to Supramolecular Architecture. Chem. Commun. 1997, 1807-1808.

28. Hannon, M. J.; Painting, C. L.; Alcock, N. W. A Metallo-Supramolecular Double-Helix Containing a Major and Minor Groove. Chem. Commun. 1999, 2023-2024.

29. Childs, L. J.; Pascu, M.; Clarke, A. J.; Alcock, N.W.; Hannon, M. J. Using Noncovalent Intra-Strand and Inter-Strand Interactions to Prescribe Helix Formation Within a Metallo-Supramolecular System. Chem. Eur. J 2004, 10, 4291-4300.

30. Childs, L. J.; Malina, J.; Rolfnes, B. E.; Pascu, M.; Prieto, M. J.; Broome, M. J.; Rodger, P. M.; Sletten, E.; Moreno, V.; Rodger, A.; Hannon, M. J. A DNA-Binding Copper(i) Metallosupramolecular Cylinder that Acts as an Artificial Nuclease. Chem. Eur. J. 2006, 12, 4919-4927.

31. Olesky, A.; Blanco, A. G.; Boer, R.; Uson, I.; Aymami, J.; Rodger, A.; Hannon, M. J.; Coll, M. Molecular Recognition of a Three-Way DNA Junction by a Supramolecular Helicate. Angew. Chem. Intl. Ed. 2006, 45, 1227-1231.

32. Pascu, G. I.; Hotze, A. C. G.; Sanchez-Cano, C.; Kariuki, B. M.; Hannon, M. J. Dinuclear Ruthenium (II) Triple-Stranded Helicates: Luminescent Supramolecular Cylinders that Bind and Coil DNA and Exhibit Activity Against Cancer Cell Lines. Angew. Chem. Intl. Ed. 2007, 46, 4374-4378.

33. Senko, M. W.; Hendrickson, C. L.; Pasa-Tolic, L.; Marto, J. A.; White, F. M.; Guan, S.; Marshall, A. G. Electrospray Ionization Fourier Transform Ion Cyclotron Resonance at 9.4 T. Rapid Commun. Mass Spectrom. 1996, 10, 1824-1828.

34. Hakansson, K.; Chalmers, M. J.; Quinn, J. P.; McFarland, M. A.; Hendrickson, C. L.; Marshall, A. G. Combined ECD and IRMPD for Multistage MS/MS in a FTICR Mass Spectrometer. Anal. Chem. 2003, 75, 3256-3262.

35. Tsybin, Y. O.; Hendrickson, C. L.; Beu, S. C.; Marshall, A. G. Impact of Ion Magnetron Motion on Electron Capture Dissociation Fourier Transform Ion Cyclotron Resonance Mass Spectrometry. Int. J. Mass Spectrom. 2006, 255/256, 144-149.

36. Grewal, R. N.; Rodriquez, C. F.; Shoeib, T.; Chu, I. K.; Tu, Y. P. Hopkinson, A. C.; Siu, K. W. M. Elimination of $\mathrm{AgR}\left(\mathrm{R}=\mathrm{H}, \mathrm{CH}_{3}, \mathrm{C}_{6} \mathrm{H}_{5}\right)$ from Collisionally-Activated Argentinated Amines. Eur. J. Mass Spectrom. 2000, 6(2), 187-192.

37. Shi, T. J.; Zhao, J. F.; Siu, K. W. M.; Hopkinson, A. C. Fragmentation of Singly-Charged Silver $\alpha, \omega$-Diaminoalkane Complexes: Competition Between the Loss of $\mathrm{H}_{2}$ and AgH. Eur. J. Mass. Spectrom. 10(6), 931-940. 